\title{
頸部に発生した胸腺腫例
}

$\begin{array}{llrrr}\text { 長門 } & \text { 利純・林 } & \text { 達哉・岸部 } & \text { 幹・国部 勇 } \\ \text { 片田 } & \text { 彰博・野中 } & \text { 聡 } \cdot \text { 原㴊 } & \text { 保明 }\end{array}$

\section{A Case of Thymoma in the Neck (Cervical Thymoma)}

\author{
Toshihiro Nagato, Tatsuya Hayashi, Kan Kishibe, Isamu Kunibe, \\ Akihiro Katada, Satoshi Nonaka and Yasuaki Harabuchi \\ (Asahikawa Medical College)
}

\begin{abstract}
Thymoma is one of the most common neoplasms of the mediastinum and is the most frequent tumor in the anterosuperior compartment. However, it is a comparatively rare tumor in the neck. We report a case of thymoma in the neck (cervical thymoma).

A 35-year-old female had a tumor on the left side of the anterior neck. We suspected a thyroid tumor before surgery. A transcervical approach was adopted for complete resection of the tumor. The tumor was located just beneath the left lower lobe of the thyroid and well encapsulated. Histologically, the tumor showed a mixed proliferation of lymphocytes and epithelial cells. Histological examination demonstrated non-invasive thymoma.

Otolaryngologists should keep cervical thymoma in mind when they examine patients with a tumor in the neck.
\end{abstract}

Key words : thymoma, neck, cervical thymoma

\section{はじめに}

胸腺腫はわが国で最も発生頻度の多い縱隔腫瘍であ る1)が, 頸部に発生することは比較的まれである. 今回 われわれは頸部に発生した胸腺腫例を経験したので報告 する.

\section{症例}

症例：35 歳, 女性.

主訴：頸部腫脹.

既往歴：特記すべきことなし。

家族歷：特記すべきことなし。

現病歷: 20 歳の頃より頸部腫脹を自覚していたが放置 していた. 徐々に増大傾向を認めたため, 2001 年 5 月 26 日に近医耳鼻咽喉科を受診した。甲状腺腫瘍を疑われ， 精查加療目的にて同年 5 月 31 日に当科紹介となった.
初診時所見 : 左前頸部の甲状腺左葉下極に相当する位 置に, $60 \times 40 \mathrm{~mm}$ の弾性硬で表面平滑な腫瘤を認めた. 腫瘤の下端は胸骨の裏に入り込んでいた。嚥下運動に伴 う腫瘤の挙上は明確ではなかった。頸部リンパ節の腫脹 は認めなかった。 その他, 耳鼻咽喉科領域に明らかな異 常所見を認めなかった。

血液検查所見：甲状腺機能検查は正常であり，抗サイ ログロブリン抗体陰性, 抗ミクロゾーム抗体陰性であっ た.

頸部 X 線所見 : 気管の右側への圧排を認めた。 超音波所見: 甲状腺左葉下極に $65 \times 35 \mathrm{~mm}$ の内部不均 一な腫瘤を認めた。 甲状腺との境界が一部不明瞭であっ たが，それ以外の周囲との境界は明瞭であった。 腫瘤の 下端は縦隔内一と進展していた。

CT 所見: 甲状腺左葉下極から縦隔内にかけて比較的均 


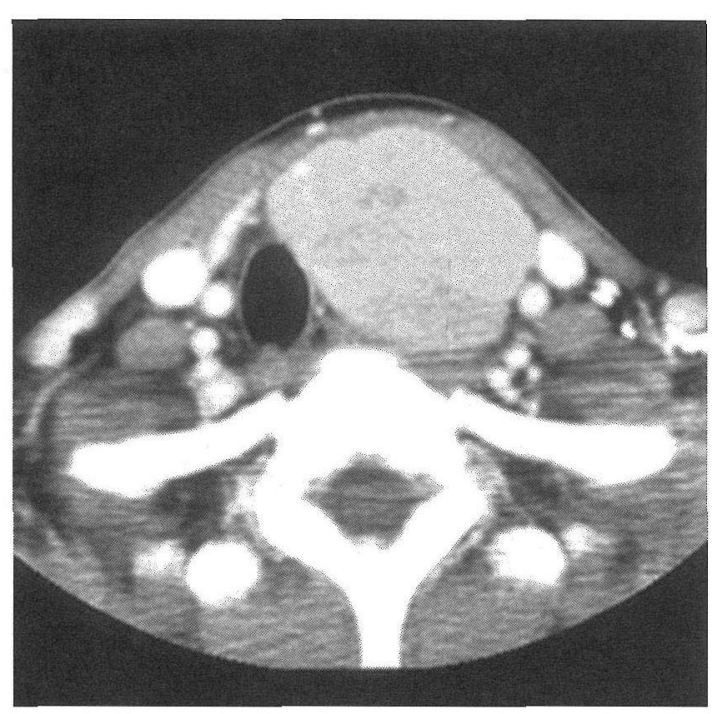

図 1 CT (造影) 所見

甲状腺左葉下極汃ら縦隔内に加けて比較的均一に造影さ れる腫瘤を認める。

一に造影される腫瘤を認めた（図 1)。

MRI 所見: CT と同部位に T1 で筋組織と等信号, T2 で やや高信号，ガドリニウムにて淡く造影され，内部に一 部隔壁様構造をもつ腫瘤を認めたが，気管や脈管への明 らかな浸潤は認めなかった（図2）。

穿刺吸引細胞診 : 大小のリンパ球を認めたが，悪性像 を示寸所見はなかった。

以上の所見より，縦隔内に進展した腺腫様甲状腺腫， 縱隔内甲状腺腫，覀性リンパ腫等を疑い，腫瘤摘出術を 施行した。術中所見では, 腫瘤は甲状腺左葉下極に接す るように存在していた。しかし，腫永と甲状腺との連続 性を完全には否定できなかったため, 腫瘤を甲状腺左葉 とともに摘出した。腫瘤と周团組織との癒着はなく, 摘 出標本は肉眼的に薄い線維性被膜で被覆されていた。内 部は黄白色の充害性腫瘤だった（図 3)。

病理組織学的所見：上皮細胞と異型のないリンパ球を 認めることから胸腺腫であり，被膜への浸潤は認められ ないことから非浸潤性胸腺腫と診断された（図 4)。

病理診断が胸腺腫であったため，重症筋無力症，赤芽 球疼，低 $\gamma$-グロブリン血症なざの合併症について精查し たが，明らかな合併症は認められなかった。

術後 2 年が経過したが, 腫瘍の再発を認めていない。

\section{考察}

胸腺腫はわが国でもっとも発生頻度の多い縱隔腫瘍で ある1)。過去の報告では，胸腺腫の大部分は前緃隔や上 縦隔に生じ，4\%程度が頸部や中縦隔，後縱隔に発生する といわれている2.

胸腺の発生は, 胎生 5 週頃に両側第 3 咽頭囊の内胚葉 上皮の一部が局所的な体内陥入を起こすことにより生じ る。そのような左右の宿入上皮が頸部を経て下方に成長 し, 胎生 8 週頃に上縦隔で互いに癒合すると同時に咽頭 囊上皮との結合関係を失う ${ }^{3)}$ 。そのため，頸部に生じる 胸腺腫の発生起源としては, 頸部の胸腺組織の胎生遺残 物や縦隔胸腺の上極などが考光られるが，発生起源の同 定については困難とする意見が多(4)5).

胸腺腫は胸腺上皮に由来する腫瘍であるが，上皮細胞 成分とリンパ球成分がさまざまな割合で混在しており, ほとんど上皮細胞からなるものからリンパ球が大部分を 占めるものまで存在する。リンパ球には異型性を認めな いため，反応性増生であると考えられている。浸潤や転 移などの悪性腫場の特徴を示す場合でも，胸腺腫細胞に は組織学的な異型が認めら机ないため, 胸腺癌とは区別 されている6.

綐隔内胸腺腫では病期分類として正岡の分類?) が広く 用いられており，病期と予後の間によい相関があるとさ れている. 肉眼的に完全に被包され，組織学的に被膜浸 潤が認められないものを I 期とし，浸潤や転移の程度で II IV 期に分類されている. I 期を非浸潤型, II 期以上を浸 潤型とし，治療方針等で区別して考えることが多い，胸 腺腫の治療の第一選択は手術による完全摘出であり, I 期 での局所再発率はきわめて低く，原則的には放射線㙩法 は必要としない。しかし，II 期以上では，術後放射線治 療を受けていない群の局所再発率が高率であったとの報 告もあり ${ }^{8)}$ ，浸潤型に対する放射線の併用療法は標準的 治療と考元られている99.

本邦における頸部に発生した胸腺腫の報告は, わ扎わ れの検索しえた限りでは, 1952 年から 2003 年までの間 に本症例を含めて 37 例報告されている (表 1) 4)5)10) 34). 年齢が記載されている 36 例の平均年齢は 51.1 歳であり, 性別は男性 8 例，女性 28 例と女性に多く認められてい る. 腫瘍の発生部位としては, 左右が記載されている 31 例中右側が 9 例, 左側が 20 例, 両側が 2 例と左側に多く 認められている. 主訴に関しては, 記載されている 29 例 中 24 例が頸部腫瘤, 2 例が嗄声, 1 例が頸部圧迫感であっ 


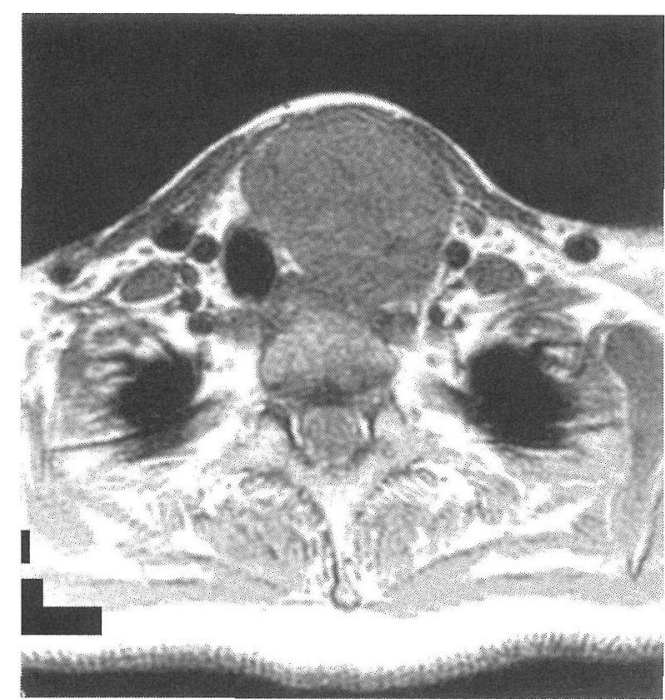

A

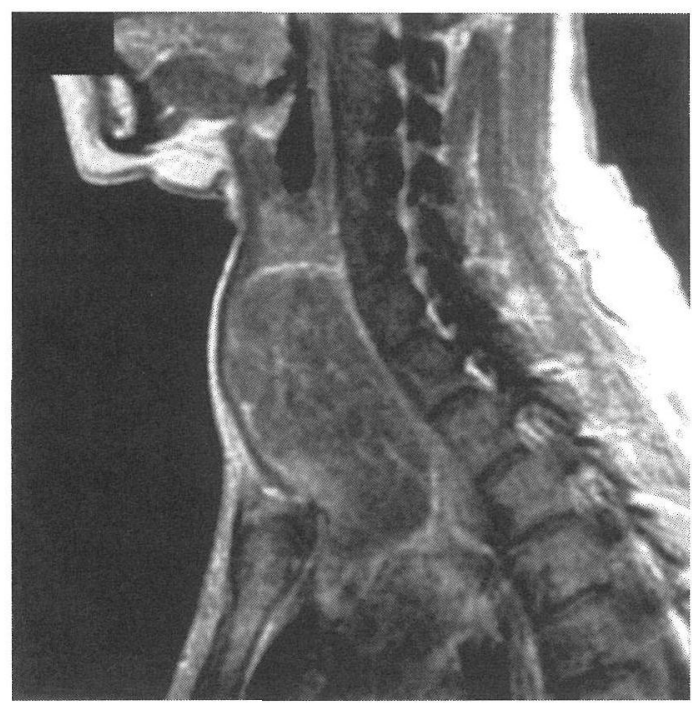

C

た。嗄声を主訴とした 2 例はいずれも浸潤型であった。 本症例では，性別は女性，発生部位は左側，主訴は頸部 腫瘤であり，いずれも従来の報告の症状，特徴と一致し ていた。重症筋無力症の合併を認めた症例は 3 例報告さ れている。そのうち 1 例は重症筋無力症の症状発現とほ ぼ同時期に前頸部の腫瘤を自覚しているが 13)，残りの 2 例は重症筋無力症の診断確定後, 画像検索にて頸部の腫 瘤を指摘されたものである27)32)。腫瘤摘出後に胸腺腫と 判明し，重症筋無力症等の合併を検索した症例は本症例 を含めて 11 例存在するが，いずれも合併を認めなかっ た。術前診断ではほとんどの症例が甲状腺腫瘍もしくは

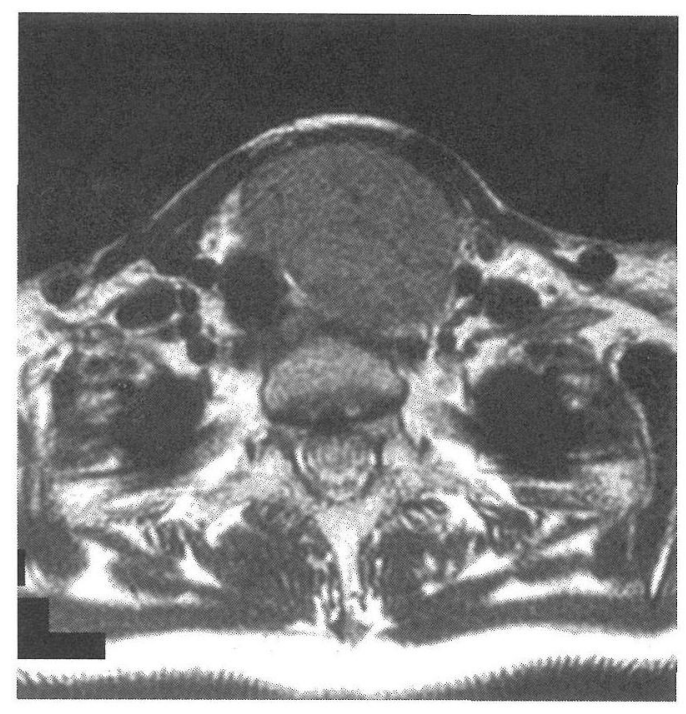

B

図 2 MRI 所見

A：T1 強調画像。甲状腺左葉下極から縦隔内にかけて 筋組織とほぼ等信号の腫溜を認める。

B ：T2 強調画像. 同部位にやや高信号の腫瘤を認める。

C：ガドリニウム造影画像. 甲状腺左葉下極から縦隔 内にかけて, 淡く造影され, 内部に一部隔壁様構造 をもつ腫瘤を認める。
悪性リンパ腫と診断されている。丸田ら ${ }^{26)}$ は，頸部に発 生した胸腺腫の穿刺吸引細胞診に関して, 縦隔胸腺腫の 組織像を反映した胸腺上皮由来の腫瘍細胞とリンパ球の two cell pattern を特徴的な所見であるとしており，これ により 7 例中 6 例を診断できたと述べている。また，術 前診断に関してはシンチグラフィーの有用性を挙げてい る文献も散見される。縱隔胸腺腫においては, ${ }^{201} \mathrm{Tl},{ }^{67} \mathrm{Ga}$ ともに集積するといわれているため，頸部に発生した胸 腺腫にも集積すると考えられる5)。悪性リンパ腫でも同 様の集積を認めるが, 胸腺腫においては201 Tl の集積がよ り高い傾向にあり，鑑別点となりらる5)15)。また，甲状 
表 1 本邦における頸部に発生した胸腺腫報告例

\begin{tabular}{|c|c|c|c|c|c|c|c|c|c|c|}
\hline 症例 & 報告者 & 年齢 & 性別 & 主訴 & 左右 & 穿刺吸引細胞診 & 術前診断 & \begin{tabular}{|l} 
重症筋無力症 \\
などの合併
\end{tabular} & 治療 & $\begin{array}{l}\text { 浸潤型, } \\
\text { 非浸潤型 }\end{array}$ \\
\hline 1 & 山田ら 10$)$ & 45 & 女 & 頸部腫瘤 & 右 & - & - & - & - & - \\
\hline 2 & 水谷 ${ }^{11)}$ & 58 & 男 & 頸部腫瘤 & 右 & 異型細胞を認めず & 悪性リンパ腫 & なし & $\begin{array}{l}\text { 腫瘍摘出十 } \\
\text { 放射線照射 }\end{array}$ & 浸潤型 \\
\hline 3 & 吉田ら & 81 & 女 & 頸部腫瘤 & 右 & - & \begin{tabular}{|l|} 
悪性腫瘍のリンパ \\
節転移
\end{tabular} & - & $\begin{array}{l}\text { 腫瘍摘出+ } \\
\text { 化学療法 }\end{array}$ & 浸潤型 \\
\hline 4 & 狩野ら & 41 & 女 & 頸部腫瘤 & - & - & - & $\begin{array}{c}\text { あり } \\
\text { (術後軽快) }\end{array}$ & 腫瘤摘出 & - \\
\hline 5 & 吉野ら & 40 & 男 & 頸部腫瘤 & 右 & 未施行 & - & - & 腫瘍摘出 & - \\
\hline 6 & \multirow{3}{*}{ 岡ら } & 47 & 男 & 頸部腫瘤 & 両 & - & 覀性リンパ腫 & - & $\begin{array}{l}\text { 腫瘤摘出+ } \\
\text { 放射線照射 }\end{array}$ & 浸潤型 \\
\hline 7 & & 41 & 女 & 頸部腫瘤 & 左 & - & 甲状腺腺腫 & - & 腫瘤摘出 & - \\
\hline 8 & & 45 & 女 & 頸部腫瘤 & 左 & - & 甲状腺近傍腫瘍 & - & 腫瘤摘出 & - \\
\hline 9 & 福田ら & 28 & 女 & 頸部腫瘤 & 右 & - & 甲状腺癌 & - & 腫瘍摘出 & - \\
\hline 10 & 福富ら 16$)$ & 50 & 女 & 莖新腫瘤 & 左 & - & 結節性甲状腺腫 & - & 腫瘤摘出 & - \\
\hline 11 & \multirow{2}{*}{ 杜ら } & 37 & 男 & 頸部腫瘤 & 左 & - & 甲状腺腫 & - & 腫瘤摘出 & 非浸潤型 \\
\hline 12 & & 36 & 女 & 頸部腫瘤 & 左 & - & 甲状腺腫 & - & 腫瘤摘出 & 非浸潤型 \\
\hline 13 & Yamashita $ら^{18)}$ & 51 & 女 & 頸部腫瘤 & 左 & - & 腺腫様甲状腺腫 & - & $\begin{array}{l}\text { 腫瘤摘出+ } \\
\text { 放射線照射 }\end{array}$ & 浸潤型 \\
\hline 14 & 岡本ら ${ }^{19)}$ & 78 & 男 & 嗄声 & 右 & - & 甲状腺乳頭癌 & - & $\begin{array}{l}\text { 腫瘤摘出+ } \\
\text { 放射線照射 }\end{array}$ & 浸潤型 \\
\hline 15 & 永来ら 20$)$ & 19 & 男 & 頸部腫瘤 & 両 & - & - & - & 腫瘤摘出 & - \\
\hline 16 & 露口ら 21$)$ & 69 & 女 & 嗄声 & 左 & - & 甲状腺癌 & - & $\begin{array}{l}\text { 腫瘤摘出+ } \\
\text { 放射線照射 }\end{array}$ & 浸潤型 \\
\hline 17 & 野村 $5^{22)}$ & 26 & 女 & 頸部腫瘤 & - & - & - & なし & \begin{tabular}{|l} 
腫瘤摘出+ \\
放射線照射
\end{tabular} & 浸潤型 \\
\hline 18 & 奥川ら 23$)$ & 53 & 女 & 頸部腫瘤 & 左 & 悪性リンパ腫 & 悪性リンパ腫 & - & $\begin{array}{l}\text { 化学療法+ } \\
\text { 腫瘤摘出 }\end{array}$ & - \\
\hline 19 & 小松ら 24$)$ & - & - & - & 左 & - & - & - & - & 浸潤型 \\
\hline 20 & 伊賀ら ${ }^{25)}$ & 62 & 女 & 頸部腫瘤 & 左 & リンパ球と上皮細胞 & - & - & 腫瘤摘出 & 浸潤型 \\
\hline 21 & \multirow{7}{*}{ 丸田ら 26$)$} & 51 & 女 & - & 左 & $\begin{array}{l}\text { 異型のないリンパ球と } \\
\text { 上皮細胞 }\end{array}$ & 胸腺腫 & なし & - & 非浸潤型 \\
\hline 22 & & 49 & 女 & - & - & $\begin{array}{l}\text { 異型のないリンパ球と } \\
\text { 上皮細胞 }\end{array}$ & 胸腺腫 & なし & - & 浸潤型 \\
\hline 23 & & 58 & 女 & - & - & $\begin{array}{l}\text { 異型のないリンパ球と } \\
\text { 上皮細胞 }\end{array}$ & 胸腺腫 & なし & - & 非浸潤型 \\
\hline 24 & & 48 & 女 & - & - & $\begin{array}{l}\text { 異型のないリンパ球と } \\
\text { 上皮細胞 }\end{array}$ & 胸腺腫 & なし & - & 浸潤型 \\
\hline 25 & & 64 & 女 & - & 左 & $\begin{array}{l}\text { 異型のないリンパ球と } \\
\text { 上皮細胞 }\end{array}$ & 胸腺腫 & なし & - & 浸潤型 \\
\hline 26 & & 53 & 女 & - & - & $\begin{array}{l}\text { 異型のないリンパ球と } \\
\text { 上皮細胞 }\end{array}$ & 胸腺腫 & なし & - & 浸潤型 \\
\hline 27 & & 64 & 男 & - & 左 & 重積性を示す腫瘍細胞 & \begin{tabular}{|l} 
悪性腫瘍のリンパ \\
節転移
\end{tabular} & なし & - & - \\
\hline 28 & 鈴木ら5) & 63 & 女 & 䫖部腫瘤 & 左 & リンパ球と上皮細胞 & 甲状腺腫瘍 & なし & 腫瘤摘出 & 浸潤型 \\
\hline 29 & 谷川ら27) & 55 & 女 & 脱毛, 複視 & 右 & リンパ球と上皮細胞 & 胸腺腫 & あり & $\begin{array}{l}\text { 腫瘤摘出を } \\
\text { 患者拒否 }\end{array}$ & - \\
\hline 30 & 神崎ら 28$)$ & 60 & 女 & 頸部腫瘤 & 左 & - & 甲状腺腫瘍 & - & 腫瘤摘出 & 非浸潤型 \\
\hline 31 & 和田ら 29$)$ & 38 & 男 & 頸部腫瘤 & 右 & - & $\begin{array}{l}\text { 類表皮囊胞, } \\
\text { 脂肪腫 }\end{array}$ & - & 腫瘤摘出 & - \\
\hline 32 & 長谷川ら & 49 & 女 & $\begin{array}{l}\text { 㫶下時頸部 } \\
\text { 圧迫感 }\end{array}$ & 左 & $\begin{array}{l}\text { リンパ球と紡錘形間質 } \\
\text { 細胞 }\end{array}$ & 悪性リンパ腫 & - & $\begin{array}{l}\text { 化学療法+ } \\
\text { 腫瘤摘出 }\end{array}$ & - \\
\hline 33 & 小山ら & 59 & 女 & 頸部腫瘤 & 左 & 悪性細胞の検出なし & 甲状腺腫瘍 & - & - & - \\
\hline 34 & 伊藤ら ${ }^{32)}$ & 51 & 女 & \begin{tabular}{|l} 
瞼の重さ挙上困難 \\
上肢
\end{tabular} & 左 & - & - & あり & 腫瘤摘出 & - \\
\hline 35 & 華岡ら ${ }^{33)}$ & 68 & 女 & 頸部腫瘤 & 左 & class II & - & - & $\begin{array}{l}\text { 腫瘤摘出+ } \\
\text { 放射線照射 }\end{array}$ & 浸潤型 \\
\hline 36 & 宮竹ら 34$)$ & 68 & 女 & 頸部腫瘤 & 右 & 甲状腺乳頭癌 & 甲状腺乳頭癌 & - & $\begin{array}{l}\text { 腫瘤摘出+ } \\
\text { 放射線照射 }\end{array}$ & 浸潤型 \\
\hline 37 & 本例 & 35 & 女 & 頸部腫瘤 & 左 & 大小のリンパ球のみ & 腺腫様甲状腺腫 & なし & 腫瘍摘出 & 非浸潤型 \\
\hline
\end{tabular}




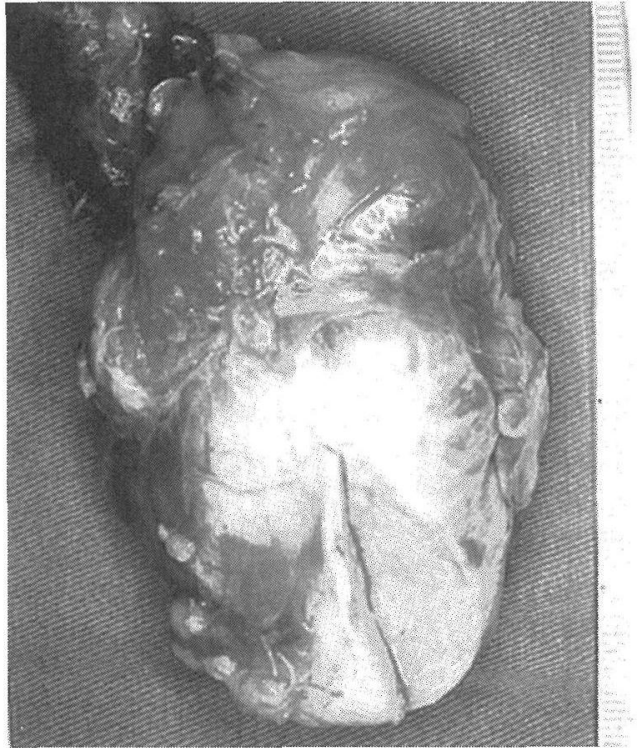

図 3 摘出標本

薄い線維性被膜で被覆されており，内部は黄白色の充実 性であった（標本下半分が割面を示している，右上部の 組織は甲状腺左葉。).

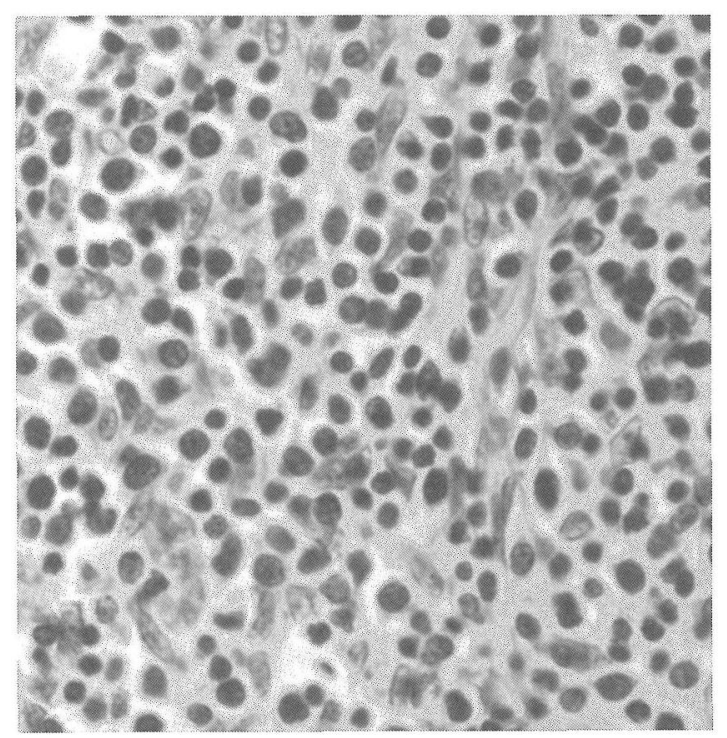

図 4 病理組織学的所見（HE 染色，×400） 上皮細胞と異型のないリンパ球を認める。

腺腫瘍に関しては，良性腫瘍は ${ }^{201} \mathrm{~T} 1,{ }^{67} \mathrm{Ga}$ ともに集積を 認めない点, 分化癌は ${ }^{201} \mathrm{~T} 1$ のみ集積を認める点, 未分化 癌は ${ }^{67} \mathrm{Ga}$ の多集積を認める点から鑑別できると報告して いる5)。非浸潤型もしくは浸潤型の記載がなされている
22 例中 6 例が非浸潤型, 16 例が浸潤型であった。浸潤型 16 例のうち，治療に関する記載があった 11 例中 8 例で 手術による腫瘤摘出後に放射線治療が施行されており, 縦隔胸腺腫の治療に準じていると考光られた。本症例に おいては，非浸潤型であったため，術後の放射線照射は 行わず経過観察とした。化学療法を施行した例が 3 例認 められるが，2 例は悪性リンパ腫との術前診断に基づい て行われたものであり, 腫瘤の縮小後に摘出術を施行し て胸腺腫々判明した症例であった ${ }^{23330) 。 ~}$

本症例では, 術前診断として縱隔内に進展した腺腫様 甲状腺腫, 縱隔内甲状腺腫, 覀性リンパ腫等を考元, 腫 瘤摘出を施行した結果, 胸腺腫であった。穿刺吸引細胞 診では典型的な two cell pattern を示してはいなかった が，異型を伴わないリンパ球を認めるなどといった特徵 を示す所見があった。頸部に胸腺腫が発生するとの認識 があり，穿刺吸引細胞診の結果を考慮してシンチグラ フィーなどのさらなる検查を行えば，術前診断は可能で あったかもしれない。一方では, 頸部胸腺腫症例の大部 分は術前に甲状腺腫瘍との診断を受けており，正確な術 前診断が不可能であったとしても，手術による完全摘出 といら治療方針は変わらなかったため, 術前診断にこだ わる必要はないとする意見もある ${ }^{199}$ 。しかし，重症筋無 力症の合併が存在する場合にクリーゼによる術中死の可 能性がある点 ${ }^{35)}$, 悪性リンパ腫との術前診断で化学療法 が施行されている症例がある点などを考慮すると, 耳鼻 咽喉科医は頸部腫瘤の鑑別に際し，胸腺由来の疾患が頸 部に発症することを念頭に入れておくべきであると思わ れる。

\section{まとめ}

1）頸部に発生した胸腺腫例を経験した。

2）頸部腫瘤の鑑別に際し,胸腺腫の存在について認識 していることが重要であると考觉られた。

本論文の要旨は, 第 64 回耳鼻咽喉科臨床学会 $(2002$ 年 6 月, 大阪府）において口演した。

\section{参考文献}

1）和田洋己, 寺松 孝: 縱隔腫瘍全国集計（1975. $7 \sim 1979.5)$. 日胸外会誌 $30: 374 \sim 378,1982$.

2) Rosai $J$ and Levine GD : Tumors of the thymus. Atlas of Tumor Pathology (Second Series). pp $34 \sim 161$, Armed Forces Institute of Pathology, Washington, D.C., 1976. 
3) Richard SS : 胸腺の発生. スネル臨床発生学 第 1 版（山内 昭雄訳). $225 \sim 226$ 頁, メディカル・サイエンス・イン ターナショナル, 東京, 1985 .

4) 岡 厚, 福光正行, 比田井耕, 他 : 異所性 (頸部) 胸腺 腫の 3 手術例. 外科診療 $20: 91 \sim 98,1978$.

5）鈴木政美, 竹生田勝次, 西嶌 渡, 他 : 頸部胸腺腫の 1 症 例. 埼玉医会誌 $32: 800 \sim 804,1998$.

6) 光冨徹哉: 症候・病態の分子メカニズム, 胸腺腫. Molecular Medicine $35: 230,1998$.

7) Masaoka A, Monden Y, Nakahara K, et al. : Follow-up study of thymomas with special reference to their clinical stages. Cancer $48: 2485 \sim 2492,1981$.

8) Haniuda M, Miyazawa M, Yoshida K, et al. : Is postoperative radiotherapy for thymoma effective? Ann Surg $224: 219 \sim$ $224,1996$.

9）岡 忠之, 綾部公懿: 主要疾患, 胸腺腫. 医学のあゆみ 3: $500 \sim 501,1999$.

10）山田 実, 安藤清史: 右側頸部に発生した原発性胸腺腫の 一剖検例. 癌 $43: 383 \sim 384,1952$.

11）水谷嘉夫：巨大頸部胸腺腫. 逓信医学 $20: 331 \sim 337,1968$.

12）吉田豊治, 吉田美枝子：頸部にみられた異所性胸腺腫の 1 例. 耳鼻臨床 $68: 995 \sim 999,1975$.

13）狩野 司, 青山安治, 荒木 威, 他: 頸部腫瘤により発見 された重症筋無力症を伴う胸腺腫の 1 例. 鳥取医誌 $5: 237$, 1976.

14）吉野 武, 広野達彦, 汐崎公太 : 頸部腫瘤を呈した胸腺腫 の I 治験例. 新潟医会誌 $91: 819,1977$.

15）福田照男, 伊丹道真, 沢 久, 他 : ${ }^{201} \mathrm{Tl}-$ Chlorede による 胸腺腫の描出. 臨放 $25: 499 \sim 502,1980$.

16）福富経昌, 松井俊行, 井上喬之: 頸部胸腺腫の 1 例. 日臨 外医会誌 $42: 886,1981$.

17）杜 英樹, 志田 寛, 森本雅己, 他 : 頸部胸腺腫の 2 治験 例. 外科 $45: 1040 \sim 1044,1983$.

18) Yamashita H, Murakami N, Noguchi S, et al. : Cervical thymoma and incidence of cervical thymus. Acta Pathol Jpn 33 : $189 \sim 194,1983$.

19）岡本高宏, 藤本吉秀, 児玉孝也, 他 : 甲状腺乳頭癌と鑑別 困難な頸部腫瘤を呈した悪性胸腺腫. 内分泌外科 2:503 507, 1985.

20）永来正隆, 酒井克治, 木下博明, 他：頸部胸腺腫の 1 治験 例. 日胸外会誌 $36: 2721,1988$.
21）露口 勝, 森本重利, 田中直臣, 他 : 甲状腺癌を思わせた 頸部胸腺腫の 1 例. 日呼外会誌 $3: 490,1989$.

22）野村 淳, 榊原淳二, 加納直行 : 頸部異所性胸腺腫の 1 例. 日耳鼻 $92: 279,1989$.

23）奥川忠正，伴野奈津子，小川法良，他：結節性甲状腺腫の 臨床像を呈した異所性胸腺腫の 1 例. 日内分泌会誌 66 ： 934, 1990.

24）小松英二, 清末一路, 三宅秀敏, 他 : 頸部胸腺腫の一例. 核医学 $30: 468,1993$.

25）伊賀芳朗，宮下 薰，茅崎康太郎，他：甲状腺腺腫をとも なった頸部異所性胸腺腫の一例。日臨外医会誌 $55: 399$, 1994.

26）丸田淳子，野口志郎，山下裕人：頸部胸腺腫の細胞診。日 臨細胞誌 $35: 289 \sim 293,1996$.

27）谷川明代，小宮山純，久保田昭彦，他：重症筋無力症と円 形脱毛症合併例にみられた頸部胸腺腫. 神経内科 $48: 303$ $\sim 304,1998$.

28）神崎 晶, 行木英生, 佐藤靖夫, 他：気管偏位で発見され た甲状腺乳頭癌を合併した頸部胸腺腫の I 症例.耳喉頭頸 $71: 35 \sim 38,1999$.

29）和田大助, 露口 勝, 三浦連人, 他: 頸部に発生した異所 性胸腺腫の 1 例。 日臨外会誌 $60: 658,1999$.

30）長谷川和彦，小山 賢，豊山浩祥，他：頸部にみられた胸 腺腫の一例。日臨細胞誌 $38: 131,1999$.

31）小山雅司，石井美砂子，渡辺賢一：甲状腺腫瘍に類似した 頸部胸腺腫の一例. 日本医放会誌 $62 ： 400,2002$.

32）伊藤伸朗, 大平貴之, 葛原茂樹：頸部異所性胸腺腫を伴っ た重症筋無力症の一例。臨床神経 $42: 415,2002$.

33）華岡 肇，窪田哲昭，松井和夫，他：胸骨上切痕部腫瘤の 2 症例. 耳鼻臨床 $109 ： 153 \sim 156,2002$.

34）宮竹英志，渡辺 紳，高松祐治，他：前頸部腫瘤として発 見された頸部浸潤性胸腺腫の一例. 日臨外会誌 $10: 2653$, 2003.

35) Johnson SB, Eng TY, Giaccone G, et al. : Thymoma: update for the new millennium. Oncologist $6: 239 \sim 246,2001$.

原稿受付：平成16年11月29日

原稿採択 : 平成 17 年 2 月 23 日

別刷請求先 : 長門利純

厂078-8510 北海道旭川市緑が丘東 2 条 1 丁目 1-1 旭川医科大学耳鼻咽喉科・頭頸部外科学講座 